\title{
Oxidative Damage of DNA Induced by the Cytochrome $c$ and Hydrogen Peroxide System
}

\author{
Nam Hoon Kim and Jung Hoon Kang* \\ Department of Genetic Engineering, Cheongju University, Cheongju 360-764, Korea
}

Received 18 April 2006, Accepted 19 May 2006

To elaborate the peroxidase activity of cytochrome $c$ in the generation of free radicals from $\mathrm{H}_{2} \mathrm{O}_{2}$, the mechanism of DNA cleavage mediated by the cytochrome $c / \mathrm{H}_{2} \mathrm{O}_{2}$ system was investigated. When plasmid DNA was incubated with cytochrome $c$ and $\mathrm{H}_{2} \mathrm{O}_{2}$, the cleavage of DNA was proportional to the cytochrome $c$ and $\mathrm{H}_{2} \mathrm{O}_{2}$ concentrations. Radical scavengers, such as azide, mannitol, and ethanol, significantly inhibited the cytochrome $c / \mathrm{H}_{2} \mathrm{O}_{2}$ systemmediated DNA cleavage. These results indicated that free radicals might participate in the DNA cleavage by the cytochrome $c$ and $\mathrm{H}_{2} \mathrm{O}_{2}$ system. Incubation of cytochrome $c$ with $\mathrm{H}_{2} \mathrm{O}_{2}$ resulted in a time-dependent release of iron ions from the cytochrome $c$ molecule. During the incubation of deoxyribose with cytochrome $c$ and $\mathrm{H}_{2} \mathrm{O}_{2}$, the damage to deoxyribose increased in a time-dependent manner, suggesting that the released iron ions may participate in a Fenton-like reaction to produce $\cdot \mathbf{O H}$ radicals that may cause the DNA cleavage. Evidence that the iron-specific chelator, desferoxamine (DFX), prevented the DNA cleavage induced by the cytochrome $c / \mathrm{H}_{2} \mathrm{O}_{2}$ system supports this mechanism. Thus we suggest that DNA cleavage is mediated via the generation of $\cdot \mathrm{OH}$ by a combination of the peroxidase reaction of cytochrome $c$ and the Fenton-like reaction of free iron ions released from oxidatively damaged cytochrome $c$ in the cytochrome $c$ l $\mathrm{H}_{2} \mathrm{O}_{2}$ system.

Keywords: Cytochrome $c$, DNA, Fenton Reaction, Peroxidase

\section{Introduction}

Cytochrome $c$ has been studied extensively because of its central role in electron transfer in living organisms. The

\footnotetext{
*To whom correspondence should be addressed.

Tel: 82-43-229-8562; Fax: 82-43-229-8432

E-mail: jhkang@cju.ac.kr
}

protein is localized on the intermembrane-space side of the inner mitochondrial membrane and participates in mitochondrial electron transport (Wilkstrom and Saraste, 1984). Recent reports implicate cytochrome $c$ in oxidative stress, which results from the run-away production of reactive oxygen species. In addition, cytochrome $c$ acts as a mediator of apoptotic cell death signals (Cai et al., 1998). The oxidative stress-mediated cellular damage and apoptotic cell death have been associated with neurodegenerative disorders, Parkinson's disease (PD) (Hashimoto et al., 1999), and cancer (Park and Kim, 2005).

During exposure to hydrogen peroxide, many proteins with metal binding sites are susceptible to oxidative damage, and free metal ions could be released (Kang and Kim, 1997). It has been reported that the reaction of hydrogen peroxide with heme proteins, such as cytochrome $c$, produces highly reactive ferrylheme species that are capable of oxidizing biomolecules and initiating lipid peroxidation (Radi et al., 1991a; 1993b). Recently, it was reported that hydrogen peroxide oxidized cytochrome $c$ to a peroxidase compound I-type intermediate, in which one oxidizing equivalent is present as an oxoferryl heme species and the other is present as the protein tyrosyl radical (Lawrence et al., 2003). The reaction of cytochrome $c$ with $\mathrm{H}_{2} \mathrm{O}_{2}$ may lead to release of iron ions from cytochrome $c$. Therefore, the transition metal, iron, may react with $\mathrm{H}_{2} \mathrm{O}_{2}$ to produce $\cdot \mathrm{OH}$ through a Fenton-like reaction. $\cdot \mathrm{OH}$ is the most powerful oxidizing species among several reactive oxygen radicals, and is able to oxidize most macromolecules including DNA, protein, lipid, and carbohydrate (Frank et al., 1989; Breen and Murphy, 1995; Dean et al., 1997). Oxidative DNA damage from reactive oxygen species (ROS) has been hypothesized to play a critical role in several diverse biological processes including mutagenesis, aging, carcinogenesis, radiation effects, and cancer chemotherapy (Ames, 1983; Cerruti, 1984; von Sonntage, 1987).

In this study, we examined the DNA cleavage caused by cytochrome $c$ and $\mathrm{H}_{2} \mathrm{O}_{2}$. Our results suggest that the DNA cleavage induced by cytochrome $c$ and $\mathrm{H}_{2} \mathrm{O}_{2}$ is due to the oxidative damage resulting from $\cdot \mathrm{OH}$ generated by $\mathrm{a}$ 
combination of the peroxidase activity of cytochrome $c$ and the Fenton-like reaction of free iron ions released from oxidatively damaged cytochrome $c$.

\section{Materials and Methods}

Materials. pUC19 plasmid DNA was prepared and purified from E. coli cultures using QIAGEN plasmid kits (Santa Clarita). Bovine cytochrome $c$, catalase, 2-deoxy-D-ribose, thiobarbituric acid, bathophenanthroline sulfonate and deferoxamine (DFX) were purchased from Sigma. Chelex 100 resin (sodium form) was obtained from Bio-Rad. All solutions were treated with Chelex 100 resin to remove traces of transition metal ions.

Analysis of DNA cleavage. Supercoiled plasmid pUC19 DNA $(1 \mu \mathrm{g})$ in $10 \mathrm{mM}$ potassium phosphate buffer $(\mathrm{pH} 7.4)$ was incubated for $2 \mathrm{~h}$ at $37^{\circ} \mathrm{C}$ with different cytochrome $c$ and $\mathrm{H}_{2} \mathrm{O}_{2}$ concentrations in a total volume of $20 \mu \mathrm{l}$. The reactions were stopped by freezing at $-80^{\circ} \mathrm{C}$. $5 \mu \mathrm{l}$ of loading buffer $(0.25 \%$ bromophenolblue, $40 \%$ sucrose) was added and the samples were analyzed by electrophoresis in $0.8 \%$ agarose in TBE buffer $(2 \mathrm{mM}$ EDTA, $89 \mathrm{mM}$ boric acid and $89 \mathrm{mM}$ Tris at $\mathrm{pH}$ 8.3). The resulting gel was stained with ethidium bromide. Bands of DNA were detected and photographed under UV light in a dark room.

Measurement of damage to deoxyribose. Detection of damage to deoxyribose was determined by measuring thiobarbituric acidreactive 2-deoxy-D-ribose oxidation products (Kang, 2004). The assay mixture contained $10 \mathrm{mM}$ potassium phosphate buffer ( $\mathrm{pH}$ 7.4), $10 \mathrm{mM}$ 2-deoxy-D-ribose, $1 \mathrm{mM} \mathrm{H}_{2} \mathrm{O}_{2}$ and $100 \mu \mathrm{M}$ protein in a total volume of $100 \mu \mathrm{l}$. The reaction was initiated by addition of $\mathrm{H}_{2} \mathrm{O}_{2}$ and incubated for $1 \mathrm{~h}$ at $37^{\circ} \mathrm{C}$. The reaction was terminated by addition of $2.8 \%$ trichloroacetic acid $(200 \mu \mathrm{l})$, PBS $(200 \mu \mathrm{l})$, and $1 \%$ thiobarbituric acid $(200 \mu \mathrm{l})$, then boiled at $100^{\circ} \mathrm{C}$ for $15 \mathrm{~min}$, after which the samples were cooled and centrifuged at 15,000 rpm for $10 \mathrm{~min}$. Results were read by uv/vis spectrophotometer (Shimadzu, $\mathrm{UV}-1601)$ at $532 \mathrm{~nm}$.

Determination of free iron ion concentration. The concentration of iron ions released from oxidatively damaged cytochrome $c$ was measured using bathophenanthroline sulfonate by the method described previously (Pieroni et al., 1994). The reaction mixture contained $100 \mu \mathrm{M}$ cytochrome $c, 1 \mathrm{mM} \mathrm{H}_{2} \mathrm{O}_{2}$ and $10 \mathrm{mM}$ potassium phosphate buffer ( $\mathrm{pH} 7.4$ ) in a total volume of $0.5 \mathrm{ml}$. The reaction was initiated by addition of $\mathrm{H}_{2} \mathrm{O}_{2}$ and incubated for $1 \mathrm{~h}$ at $37^{\circ} \mathrm{C}$. After the incubation, the mixture was then placed into UltrafreeMC filter and centrifuged at 13,000 rpm for $1 \mathrm{~h}$. The colorimetic reagent was added for analysis by a uv/vis spectrophotometer at $535 \mathrm{~nm}$. The final concentrations in the color reagent were $1 \%$ ascorbate, $0.02 \%$ bathophenanthroline sulfonate and $1 \%$ acetic acid-acetate buffer ( $\mathrm{pH} 4.5$ ).

\section{Results and Discussion}

Untreated DNA showed a major band corresponding to the

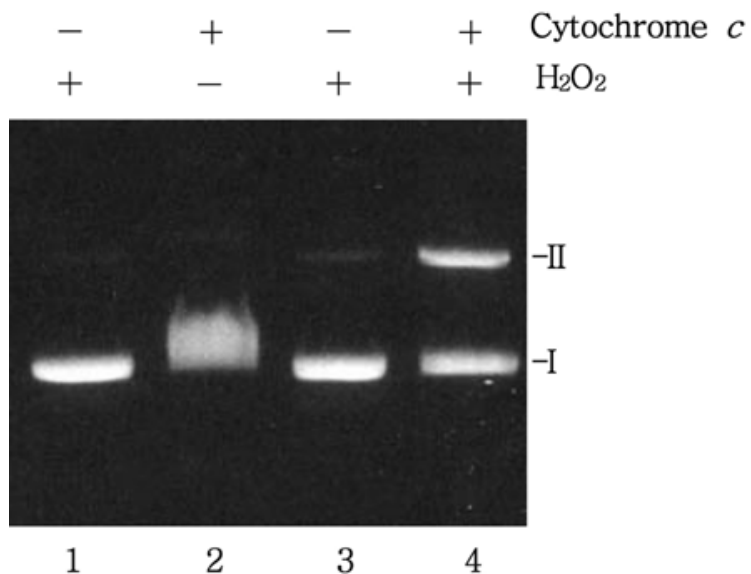

Fig. 1. DNA strand breakage after incubation with cytochrome $c$ and $\mathrm{H}_{2} \mathrm{O}_{2}$. pUC 19 DNA $(1 \mu \mathrm{g})$ was incubated at $37^{\circ} \mathrm{C}$ for $2 \mathrm{~h}$ : Lane 1, pUC 19 DNA control; lane 2, DNA $+50 \mu \mathrm{M}$ cytochrome $c$; lane 3 , DNA $+0.3 \mathrm{mM} \mathrm{H}_{2} \mathrm{O}_{2}$; lane 4 , DNA $+50 \mu \mathrm{M}$ cytochrome $c+0.3 \mathrm{mM} \mathrm{H}_{2} \mathrm{O}_{2}$. The reactions were stopped by freezing at $-80^{\circ} \mathrm{C}$. Loading buffer was added and the samples were analyzed by electrophoresis on $0.8 \%$ agarose gel. I and II indicate the positions of the supercoiled and nicked circular DNA plasmid forms, respectively.

supercoiled form (form I) and a minor band corresponding to nicked circular form (form II) (Fig. 1, lane 1). Plasmid DNA remained intact after incubation with $50 \mu \mathrm{M}$ cytochrome $c$ (Fig. 1, lane 2) or $0.3 \mathrm{mM} \mathrm{H}_{2} \mathrm{O}_{2}$ (Fig. 1, lane 3) alone. However, when DNA was incubated in a mixture of cytochrome $c$ and $\mathrm{H}_{2} \mathrm{O}_{2}$, the DNA damage occurred (Fig. 1, lane 4). This indicates that both cytochrome $c$ and $\mathrm{H}_{2} \mathrm{O}_{2}$ were required to cause strand breaks in the DNA. The effect of the concentrations of cytochrome $c$ and $\mathrm{H}_{2} \mathrm{O}_{2}$ on the production of DNA strand breaks was then studied. The DNA cleavage increased dose-dependently with doses of up to $100 \mu \mathrm{M}$ cytochrome $c$ (Fig. 2A) and $1 \mathrm{mM} \mathrm{H}_{2} \mathrm{O}_{2}$ (Fig. 2B), respectively. Previous studies have shown that the reaction of cytochrome $c$ with $\mathrm{H}_{2} \mathrm{O}_{2}$ generates a free radical that oxidizes amino acid residues at or near the cation-binding site, which then introduces carbonyl groups. Such an oxidative modification is an indicator of oxidative stress and may be significant in several physiological and pathological processes (Davies, 1986; Oliver, et al., 1987).

The participation of free radicals in the DNA damage by the cytochrome $c / \mathrm{H}_{2} \mathrm{O}_{2}$ system was studied by examining the protective effect of radical scavengers. When plasmid DNA was incubated with cytochrome $c$ and $\mathrm{H}_{2} \mathrm{O}_{2}$ in the presence of azide, mannitol, or ethanol at $37^{\circ} \mathrm{C}$ for $2 \mathrm{~h}$, all scavengers significantly prevented the DNA cleavage (Fig. 3). The ability of radical scavengers to protect DNA from damage indicates that free radicals may participate in the mechanism of strand breaks produced by the cytochrome $c$ and $\mathrm{H}_{2} \mathrm{O}_{2}$ system.

Cellular metabolism has been shown to generate the reactive oxygen species such as hydrogen peroxide, hydroxyl radical, and superoxide radical (Cerruti, 1984). Trace metals 


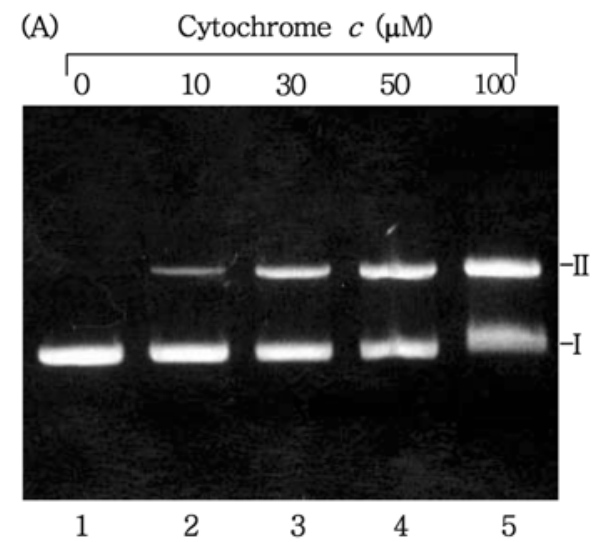

(B)

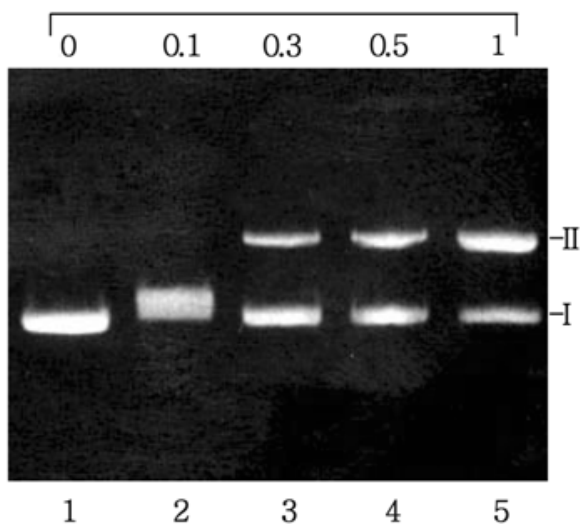

Fig. 2. Effects of cytochrome $c$ and $\mathrm{H}_{2} \mathrm{O}_{2}$ concentrations on DNA strand breakage. (A) pUC 19 DNA $(1 \mu \mathrm{g})$ was incubated with increasing doses $(0-100 \mu \mathrm{M})$ of cytochrome $c$ and $0.3 \mathrm{mM}$ $\mathrm{H}_{2} \mathrm{O}_{2}$ at $37^{\circ} \mathrm{C}$ for $2 \mathrm{~h}$. (B) pUC 19 DNA $(1 \mu \mathrm{g})$ was incubated with $50 \mu \mathrm{M}$ cytochrome $c$ and increasing doses $(0-1 \mathrm{mM})$ of $\mathrm{H}_{2} \mathrm{O}_{2}$ at $37^{\circ} \mathrm{C}$ for $2 \mathrm{~h}$.

such as copper and iron that are present in biological systems may interact with active oxygen species, ionizing radiation, or microwaves to damage macromolecules (Prutz, 1984; Samuni et al., 1984; Goldstein and Czapski, 1986; Sagripanti et al., 1987; von Sonntage, 1987; Imlay et al., 1988). The cleavage of metalloproteins by oxidative damage may lead to increases in the levels of metal ions in biological cells. We investigated the release of iron in the reaction of cytochrome $c$ with $\mathrm{H}_{2} \mathrm{O}_{2}$. During incubation of $100 \mu \mathrm{M}$ cytochrome $c$ with $1 \mathrm{mM} \mathrm{H}_{2} \mathrm{O}_{2}$, free iron ions gradually increased as a function of time (Fig. 4). It has been reported that iron ions could stimulate the Fenton-like reaction to produce $\cdot \mathrm{OH}$, which mediates DNA strand breakage (Tachon, 1989). Attack of $\cdot \mathrm{OH}$ on the sugar, 2-deoxyribose, produces a huge variety of products, some of which are mutagenic in bacterial systems. Some of the fragmentation products can be detected by adding thiobarbituric acid (TBA) to the reaction mixture, resulting in formation of a pink (TBA) $)_{2}$-MDA chromogen (Halliwell and Gutteridge, 1981). This can be used to detect $\cdot \mathrm{OH}$ production, although it is unclear whether or not some other ROS can also degrade

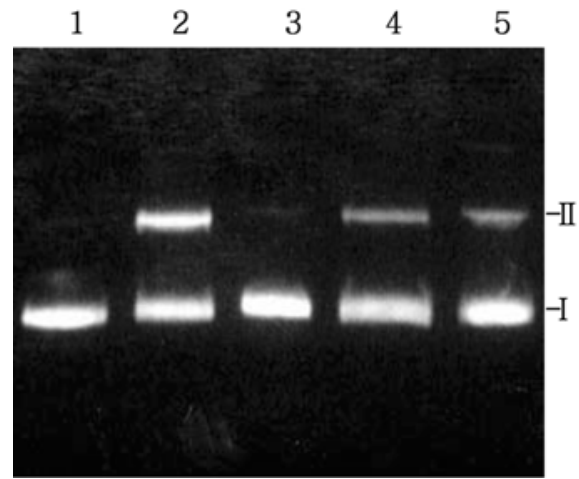

Fig. 3. Effect of radical scavengers on DNA strand breakage induced by cytochrome $c$ and $\mathrm{H}_{2} \mathrm{O}_{2}$. pUC 19 DNA was incubated with $50 \mu \mathrm{M}$ cytochrome $c+0.3 \mathrm{mM} \mathrm{H}_{2} \mathrm{O}_{2}$ in the presence of a radical scavenger. Lane 1, DNA alone; lane 2, no addition of effector; lane 3, $200 \mathrm{mM}$ azide; lane 4, $200 \mathrm{mM}$ mannitol; lane $5,500 \mathrm{mM}$ ethanol.

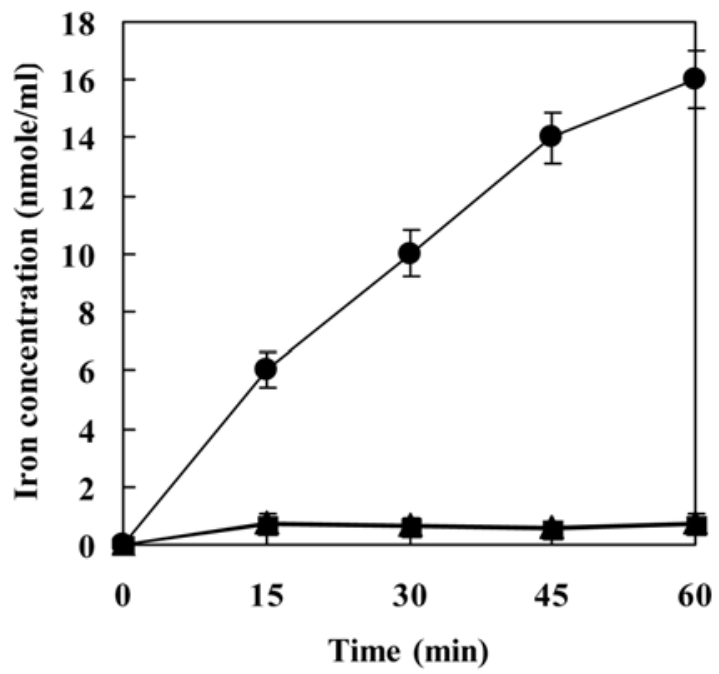

Fig. 4. Iron release in the cytochrome $c$ and $\mathrm{H}_{2} \mathrm{O}_{2}$ system. The samples were incubated in $10 \mathrm{mM}$ potassium phosphate buffer $\left(\mathrm{pH} \mathrm{7.4)}\right.$ at $37^{\circ} \mathrm{C}$ for various incubation periods with the following: $100 \mu \mathrm{M}$ cytochrome $c$ alone $(\boldsymbol{\square}) ; 1 \mathrm{mM} \mathrm{H}_{2} \mathrm{O}_{2}$ alone $(\boldsymbol{\Delta})$; $100 \mu \mathrm{M}$ cytochrome $c$ plus $1 \mathrm{mM} \mathrm{H}_{2} \mathrm{O}_{2}(\mathbf{O})$. Free iron ion concentrations were determined by a colorimetic reagent utilizing bathophenanthroline sulfonate.

deoxyribose. Our results showed that damage to deoxyribose was induced by the cytochrome $c$ and $\mathrm{H}_{2} \mathrm{O}_{2}$ system (Fig. 5). The result suggests that $\cdot \mathrm{OH}$ may participate in the cytochrome $c / \mathrm{H}_{2} \mathrm{O}_{2}$-mediated DNA cleavage. It has been reported that berberine inhibited the cytochrome $c / \mathrm{H}_{2} \mathrm{O}_{2}$ mediated DNA strand breakage through the scavenging of superoxide anion (Choi et al., 2001). In this study, however, superoxide dismutase could not inhibit the cytochrome $\mathrm{cl}$ $\mathrm{H}_{2} \mathrm{O}_{2}$-mediated DNA strand breakage (data not shown). Therefore, we assumed that the cytochrome $c / \mathrm{H}_{2} \mathrm{O}_{2}$-mediated DNA strand breakage might occur through a Fenton-like 


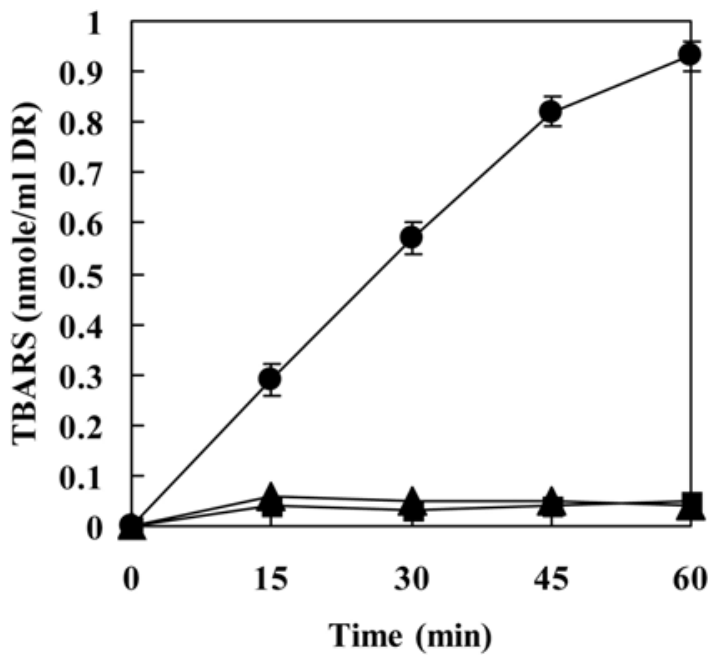

Fig. 5. 2-Deoxy-D-ribose degradation in the cytochrome $c$ and $\mathrm{H}_{2} \mathrm{O}_{2}$ system. $10 \mathrm{mM}$ 2-deoxy-D-ribose was incubated in $10 \mathrm{mM}$ potassium phosphate buffer $(\mathrm{pH} 7.4)$ at $37^{\circ} \mathrm{C}$ for various incubation periods with the following: $100 \mu \mathrm{M}$ cytochrome $c$ alone $(\boldsymbol{\square})$; $1 \mathrm{mM} \mathrm{H} \mathrm{O}_{2}$ alone (A); $100 \mu \mathrm{M}$ cytochrome $c$ plus $1 \mathrm{mM} \mathrm{H}_{2} \mathrm{O}_{2}$ (O).

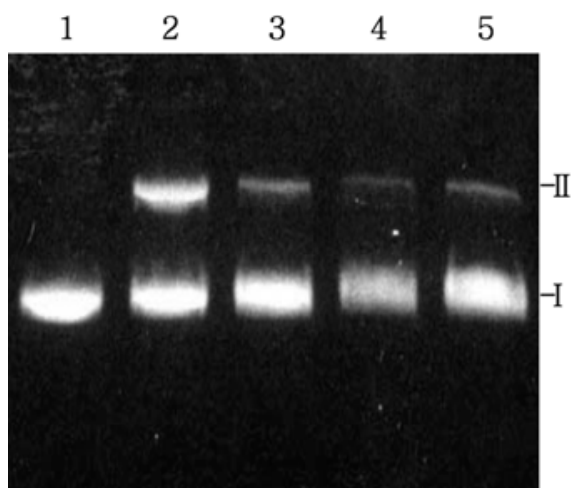

Fig. 6. Effect of DFX on DNA strand breakage induced by the cytochrome $c$ and $\mathrm{O}_{2}$ system. pUC 19 DNA was incubated with $50 \mu \mathrm{M}$ cytochrome $c$ and $0.3 \mathrm{mM} \mathrm{H}_{2} \mathrm{O}_{2}$ in the presence of various concentrations of DFX. Lane 1, DNA alone; lane 2, no addition of effector; lane 3, $1 \mathrm{mM}$ DFX; lane 4, $5 \mathrm{mM}$ DFX; lane 5, $10 \mathrm{mM}$ DFX.

reaction. The participation of iron ions in the production of DNA strand breaks was studied by examining the protective effect of the iron chelator, DFX. The DNA cleavage was effectively inhibited by $1 \mathrm{mM}$ DFX (Fig. 6). The results indicate that free iron ions are involved in DNA cleavage by the cytochrome $c / \mathrm{H}_{2} \mathrm{O}_{2}$ system.

In conclusion, the present results indicated that DNA cleavage was induced by the reaction of cytochrome $c$ with $\mathrm{H}_{2} \mathrm{O}_{2}$, involving $\cdot \mathrm{OH}$ generation from $\mathrm{H}_{2} \mathrm{O}_{2}$. The $\cdot \mathrm{OH}$ radicals were generated through a combination of the peroxidase reaction of cytochrome $c$ and the Fenton-like reaction of free iron ions released from oxidatively damaged cytochrome $c$. DNA damage caused by the cytochrome $c / \mathrm{H}_{2} \mathrm{O}_{2}$ system could be relevant in diseases where mitochondrial dysfunction is elevated, such as Parkinson's disease (Schapira, 1994). It has been reported that at least $0.1 \mathrm{mM} / \mathrm{min}_{2} \mathrm{O}_{2}$ will be produced continuously under physiological conditions; this rate increases in adverse conditions such as hyperoxia or ischemia and reperfusion (Boveries et al., 1972; Britton et al., 1987). Hence, in these abnormal conditions, the modification of human cytochrome $c$ using $\mathrm{H}_{2} \mathrm{O}_{2}$ as a substrate could be potentiated, resulting in DNA damage.

\section{References}

Ames, B. N. (1983) Dietary carcinogens and anticarcinogens. Oxygen radicals and degenerative diseases. Science 221, 12561264.

Boveries, A., Oshino, N. and Chance, B. (1972) The cellular production of hydrogen peroxide. Biochem. J. 128, 617-630.

Breen, A. P. and Murphy, J. A. (1995) Reactions of oxyl radicals with DNA Free Radic. Biol. Med. 18, 1033-1077.

Britton, R. S., Bacon, B. R. and Recknagel, R. O. (1987) Lipid peroxidation and associated hepatic organelle dysfunction in iron overload. Chem. Phys. Lipids 45, 207-239.

Cai, J., Yang, J. and Jones, D. P. (1998) Mitochondrial control of apoptosis: the role of cytochrome c. Biochim. Biophys. Acta 1366, 139-149.

Cerruti, P. A. (1994) Oxy-radicals and cancer. Lancet 344, 862863.

Choi, D.-S., Kim, S.-J. and Jung, M. Y. (2001) Inhibitory activity of berberine on DNA strand cleavage induced by hydrogen peroxide and cytochrome c. Biosci. Biotechnol. Biochem. 65, 452-455.

Davies, K. J. (1986) Intracellular proteolytic systems may function as secondary antioxidant defenses: a hypothesis. J. Free Radic. Biol. Med. 2, 155-173.

Dean, R. T., Fu, S., Stocker, R. and Davies, M. J. (1997) Biochemistry and pathology of radical-mediated protein oxidation. Biochem. J. 324, 1-18.

Frank, H., Thiel, D. and MacLoad, J. (1989) Mass spectrometric detection of cross-linked fatty acids formed during radicalinduced lesion of lipid membranes. Biochem. J. 260, 873-878.

Goldstein, S. and Czapski, G. (1986) The role and mechanism of metal ions and their complexes in enhancing damage in biological systems or in protecting these system. J. Free Radic. Biol. Med. 2, 3-11.

Halliwell, B. and Gutteridge, J. M. (1981) Formation of thiobarbituric-acid-reactive substance from deoxyribose in the presence of iron salts: the role of superoxide and hydroxyl radicals. FEBS Lett. 128, 347-352.

Hashimoto, M., Takeda, A., Hsu, L. J., Takenouchi, T. and Masliah, E. (1999) Role of cytochrome $c$ as a stimulator of alpha-synuclein aggregation in Lewy body disease. J. Biol. Chem. 274, 28849-28852.

Imlay, J. A., Chin, S. M. and Linn, S. (1988) Toxic DNA damage by hydrogen peroxide through the Fenton reaction in vivo and in vitro. Science 240, 640-642.

Kang, J. H. (2004) Modification of Cu,Zn-superoxide dismutase by oxidized catecholamines. J. Biochem. Mol. Biol. 37, 325329. 
Kang, J. H. and Kim, S. M. (1997) Fragmentation of human $\mathrm{Cu}, \mathrm{Zn}$-superoxide dismutase by peroxidative reaction. Mol. Cells 7, 553-558.

Lawrence, A., Jones, C. M., Wardman, P. and Burkitt, M. J. (2003) Evidence for the role of a peroxidase compound I-type intermediate in the oxidation of glutathione, $\mathrm{NADH}$, ascorbate, and dichlorofluorescin by cytochrome $c / \mathrm{H}_{2} \mathrm{O}_{2}$. Implications for oxidative stress during apoptosis. J. Biol. Chem. 278, 2941029419.

Oliver, C. N., Levine, R. L. and Stadtman, E. R. (1987) A role of mixed-function oxidation reactions in the accumulation of altered enzyme forms during aging. J. Am. Geriatr. Soc. 35, 947-956.

Park, J.-H. and Kim, T,-H. (2005) Release of cytochrome $c$ from isolated mitochondria by etoposide. J. Biochem. Mol. Biol. 38, 619-623.

Pieroni, L., Khalil, L., Charlotte, F., Poynard, T., Piton, A., Hainque, B. and Imbert-Bismut, F. (2001) Comparison of bathophenanthroline sulfonate and ferene as chromogens in colorimetric measurement of low hepatic iron concentration. Clin. Chem. 47, 2059-2061.

Prutz, W. A. (1984) Inhibition of DNA-ethidium bromide intercalation due to free radical attack upon DNA. II. Copper(II)-catalysed DNA damage by $\mathrm{O}_{2}^{--}$. Radiat. Environ. Biophys. 23, 7-18.
Radi, R, Thomson, L., Rubbo, H. and Prodanov, E. (1991a) Cytochrome $c$-catalyzed oxidation of organic molecules by hydrogen peroxide. Arch. Biochem. Biophys. 288, 112-117.

Radi, R., Sims, S., Cassina, A. and Turrens, J. F. (1993b) Roles of catalase and cytochrome $c$ in hydroperoxide-dependent lipid peroxidation and chemiluminescence in rat heart and kidney mitochondria. Free Radic. Biol. Med. 15, 653-659.

Sagripanti, J. L., Swicord, M. L. and Davis, C. C. (1987) Microwave effects on plasmid DNA. Radiat. Res. 110, 219231.

Samuni, A., Chevion, M. and Czapski, G. (1984) Roles of copper and $\mathrm{O}_{2}$ in the radiation-induced inactivation of $\mathrm{T} 7$ bacteriophage. Radiat. Res. 99, 562-572.

Schapira, A. H. (1994) Evidence for mitochondrial dysfunction in Parkinson's disease - a critical appraisal. Mov. Disord. 9, 125138.

Tachon, P. (1989) Ferric and cupric ions requirement for DNA single-strand breakage by $\mathrm{H}_{2} \mathrm{O}_{2}$. Free Radic. Res. Commun. 7, $1-10$.

von Sonntag, C. (1987) The Chemical Basis of Radiation Biology, Taylor \& Francis, New York, USA.

Wikstrom, M. and Saraste, M. (1984) Cytochrome oxidase; in Bioenegetics, Ernster, L., (ed.) pp. 49-94, Elsevier Science Publishers B. V., Amsterdam, Netherlands. 